JURNAL KETAHANAN NASIONAL

Vol. 24, No.2, Agustus 2018, Hal 170-191

DOI:http://dx.doi.org/ 10.22146/jkn.36679

ISSN:0853-9340(Print), ISSN:2527-9688(Online)

Online sejak 28 Desember 2015 di :http://jurnal.ugm.ac.id/JKN

VOLUME 24

No. 2, Agustus 2018

Halaman 170-191

\title{
Pengaruh Konversi Lahan Gambut Terhadap Ketahanan Lingkungan di DAS Kampar Provinsi Riau Sumatera
}

\author{
Wirdati Irma \\ Sekolah Pascasarjana Universitas Gadjah Mada \\ Fakultas MIPA dan KESEHATAN Universitas Muhammadiyah Riau \\ Email: auxiella@yahoo.co.id \\ Totok Gunawan \\ Fakultas Geografi UGM, Yogyakarta \\ Email: totokgunawan@yahoo.co.id \\ Suratman \\ Fakultas Geografi UGM, Yogyakarta \\ Email: suratmanworo@ugm.ac.id
}

\begin{abstract}
Conversion of peatlands into production land caused a decline in environmental quality. This would result in the resilience of the peatland environment to be threatened. The objective of this research was to knew the shape of peatland conversion in each peat depth which caused the decrease of environmental quality, and to knew resilience level the extent of peat land cover for vegetation biodiversity in Riau Kampar Watershed.

The method used in this research was survey and transect plot. Transect plots was used to calculated the biodiversity of peatland vegetation.

The results showed that the form of conversion of peatlands that occurred in Kampar Watershed of Riau Province in the form of oil palm plantation, rubber, industrial plantation forest and settlement on peat soil with shallow depth until deep depth ranged between $47 \mathrm{~cm}-883 \mathrm{~cm}$. Vegetation biodiversity index value of $0-2,83$ with low to moderate category.
\end{abstract}

Keywords: Conservation, Peatland, Environmental Resilience, Vegetation Biodiversity, Kampar Watershed.

\begin{abstract}
ABSTRAK
Konversi lahan gambut menjadi lahan produksi menyebabkan penurunan kualitas lingkungan. Hal demikian mengakibatkan ketahanan lingkungan lahan gambut menjadi terancam. Tujuan penelitian adalah untuk mengetahui bentuk konversi lahan gambut pada masing-masing kedalaman gambut yang menyebabkan penurunan kualitas lingkungan, dan mengetahui sejauhmana ketahanan tutupan lahan gambut biodiversitas vegetasi di DAS Kampar Provinsi Riau.

Metode yang digunakan dalam penelitian adalah survey dan transek plot. Transek plot digunakan untuk menghitung biodiversitas vegetasi lahan gambut.

Hasil penelitian menunjukkan bahwa bentuk konversi lahan gambut yang terjadi di DAS Kampar Provinsi Riau Sumatera berupa perkebunan kelapa sawit, karet, hutan tanaman industri, dan permukiman pada lahan gambut yang mempunyai kedalaman dangkal sampai pada kedalaman sangat dalam, berkisar antara $47 \mathrm{~cm}-883 \mathrm{~cm}$. Nilai Indeks biodiversitas vegetasi sebesar 02,83 dengan kategori rendah sampai sedang.
\end{abstract}

Kata kunci : Konversi, Lahan Gambut, Ketahanan Lingkungan, Biodiversitas Vegetasi, DAS Kampar 


\section{PENGANTAR}

Ketahanan lingkungan adalah salah satu bagian dari ketahanan wilayah, yang diupayakan guna menjamin keamanan halayak ramai dari munculnya bahaya lingkungan yang diakibatkan baik secara alami oleh alam maupun disengaja oleh perbuatan manusia. Ketahanan lingkungan harus menjadi tanggung jawab bersama pada lapisan masyarakat di dalam suatu ketahanan wilayah, baik stakeholder dalam hal ini pemerintah pengambil kebijakan, pihak swasta yang banyak melakukan kegiatan usaha maupun masyarakat umum di dalam suatu ketahanan lingkungan.

Salah satu komponen ketahanan lingkungan adalah lahan gambut yang saat ini menjadi sorotan dunia dan hangat diperbincangan dalam setiap perdebatan lingkungan baik secara nasional maupun internasioanl. Lahan gambut adalah lahan jenuh air yang tersusun dari bahan organik $(>12 \%)$, terjadi karena akumulasi sisa-sisa tumbuhan dan jaringan tumbuhan yang melapuk dengan ketebalan lebih dari $50 \mathrm{~cm}$ (Sukandarrumudi, 2008; Wahyunto, 2005; dan Cassel, 1997). Akumulasi yang terjadi diakibatkan oleh lambatnya laju dekomposisi dibanding dengan laju penumpukan bahan organik yang tergenang air dalam jangka waktu lama (Radjagukguk, 2000; Sabiham, 2007).

Tidak semua tumbuhan mati dapat berubah menjadi gambut, ada beberapa syarat untuk dapat menjadi gambut, yaitu (1) Terdapatnya kawasan yang jenuh air sepanjang tahun yang mengakibatkan rendahnya kadar oksigen, (2). Terjadinya proses dekompossi secara terus menerus terhadap tumbuhan yang sudah mati, (3). Sifat asam pada air tanah gambut menyebabkan terhalangnya proses anaerob yang dilakukan bakteri, (4). Semakin tebalnya timbunan sisa tumbuhan mati, (5). Proses pengendapan sedimen mineral tidak berlangsung secara terus-menerus, dan (6). Terbentuknya jelly akibat proses biokimia (Sukandarrumidi, 2009).

Menurut klasifikasi tanah, lahan gambut masuk ke dalam taksonomi histosol yaitu tanah yang berasal dari bahan organik (Soil Survey Staff, 1999). Barchia (2012) menyatakan bahwa lahan gambut dikategorikan ke dalam lahan marginal. Lahan gambut mempunyai berbagai macam tipe, berdasarkan ketebalan lapisan gambut bahan organik pembentuk gambut. Gambut dapat diklasifikasikan menjadi 4 yaitu (1). Gambut dangkal adalah lahan gambut dengan ketebalan lapisan bahan organik antara 50-100 cm, (2). Gambut tengahan adalah lahan gambut dengan ketebalan lapisan bahan organik antara 100-200 cm, (3). Gambut dalam adalah lahan gambut dengan ketebalan lapisan bahan organik antara 200-300 cm, dan (4). Gambut sangat dalam adalah lahan gambut dengan ketebalan lapisan bahan organik $>300$ cm (Barchia, 2012).

Lahan gambut memberikan manfaat dan fungsi bagi masyarakat untuk ketahanan lingkungan berupa ekologi, ekonomi dan sosial. Ketiga komponen ketahanan lingkungan ini dapat diwujudkan dengan tetap menjaga dan mempertahankan kelestariannya. Lahan gambut merupakan salah satu kekayaan alam yang dianugerahi oleh Sang Pencipta untuk dikelola dan digunakan dengan sebaik-baiknya untuk kesejahteraan manusia. Jaya (2018) melaporkan bahwa alam dan kesuburan bumi Indonesia merupakan modal pembangunan yang harus dirawat dan dipertahankan untuk memenuhi kebutuhan seluruh masyarakat. Lahan gambut juga dapat menghasilkan panas bumi yang menjadi sumber ketahanan 
energi terbarukan karena lambat laun sisa tumbuhan berupa bahan organik penyusun lahan gambut dapat menjadi fosil. Gambut kering diklasifikasikan oleh PBB (Perserikatan Bangsa-Bangsa) sebagai bahan bakar fosil terbarukan dengan karakter yang mirip dengan batubara (WCED, 1987).

Keberadaan lahan gambut di Daerah Aliran Sungai (DAS) Kampar Provinsi Riau Sumatera terbentang dari DAS bagian tengah hingga DAS bagian hilir. Kategori kedalaman lahan gambut di DAS ini bervariasi, mulai dari yang dangkal sampai dengan sangat dalam. Lahan gambut di DAS Kampar didominasi oleh kategori sangat dalam dan sebagian besar berada di hilir DAS Kampar. Keberadaan lahan gambut DAS Kampar bisa dilihat pada gambar 1 .

Lahan gambut di DAS Kampar Riau Sumatera saat ini sudah banyak mengalami konversi. Ekspansi sektor perkebunan dan hutan tanaman industri di daerah ini menjadikan dalam skala besar pembentukan drainase dan konversi lahan gambut (Casson, 2002; Koh \& Wilcove, 2008; Thorburn \& Kull, 2015). Menurut Rustiadi dan Reti (2008), dalam Janti dkk (2016). Konversi lahan gambut berakibat nyata menurunnya ketahanan lingkungan. Konversi lahan yang terjadi membawa lahan gambut tidak dapat berfungsi sesuai dengan peruntukannya. Regulasi hukum yang menyangkut konversi lahan sudah banyak dituangkan dalam peraturan dan perundangundangan, namun sejauh ini pelaksanaannya masih tidak sesuai dengan aturan yang telah dibuat. Hal ini terkendala karena kurangnya koordinasi dan pelaksanaan kebijakan dalam konsistensi perencanaan yang telah dibuat (Iqbal dan Sumaryanto, 2007).

Gambar 1

Peta Sebaran Lahan Gambut DAS Kampar Provinsi Riau Sumatera

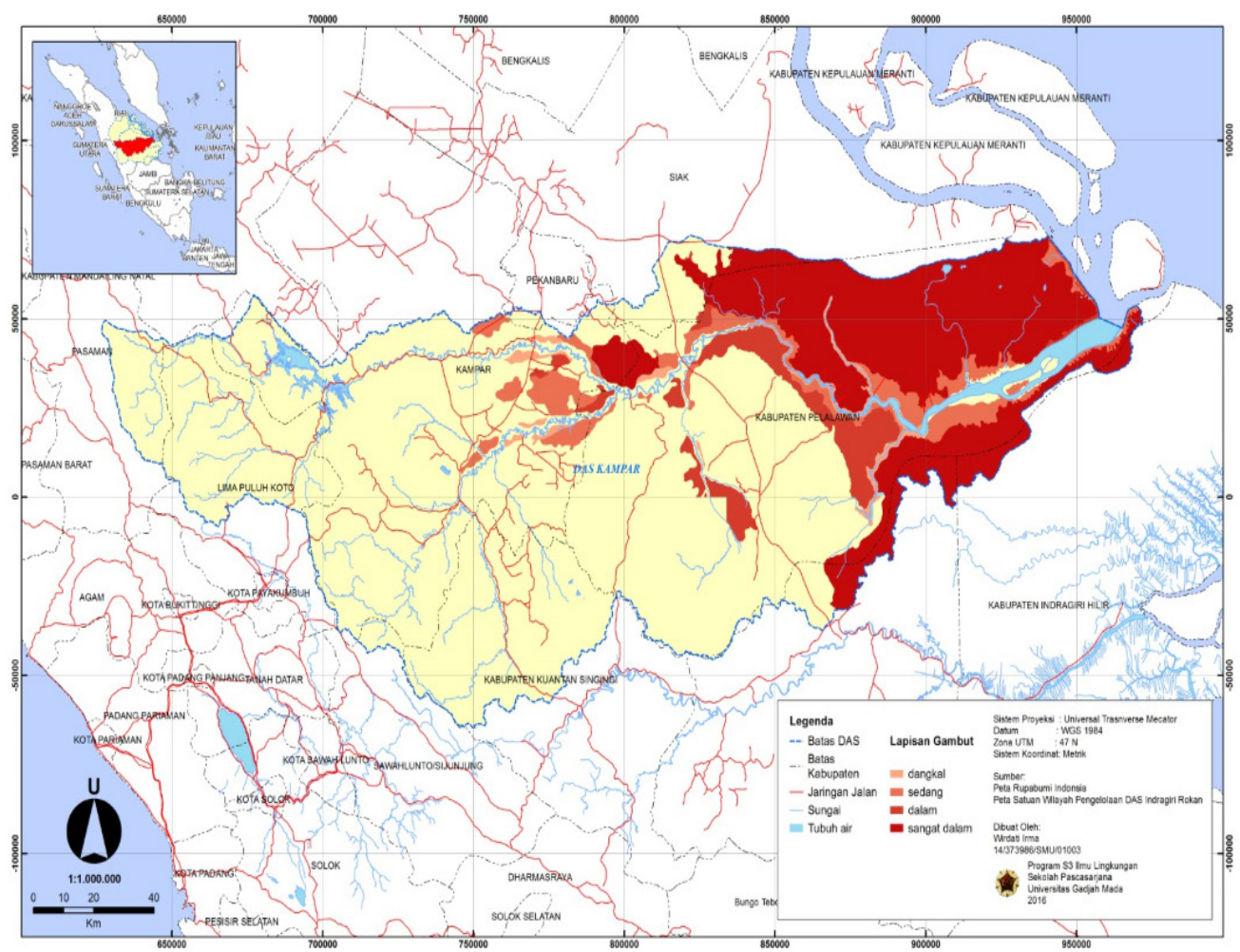

Sumber : Gambar primer, 2018 
Lebih lanjut, laju pertumbuhan jumlah penduduk dan kebutuhan lahan mengakibatkan lahan gambut dikonversi menjadi lahan produktif untuk memenuhi kebutuhan hidup. Fenomena ini dapat dikaitkan dengan berkurangnya hutan di tanah mineral, lahan gambut dan terus meningkatnya permintaan untuk produk pertanian (Miettinen dkk, 2012). Penanganan lahan gambut yang tidak sesuai dengan proporsinya dapat mengakibatkan ketahanan lingkungan menurun dan rusak. Ketahanan lingkungan lahan gambut merupakan hal yang sangat penting bagi keberlangsungan ekosistem DAS Kampar Provinsi Riau Sumatera.

Rusaknya lingkungan lahan gambut dapat menyebabkan kerentanan bencana pada lingkungan lahan gambut. Timbulnya bencana seperti kebakaran, asap dan banjir pada lahan gambut merupakan ancaman besar bagi ketahanan wilayah (Asrofi, 2017). Menurut Lemhannas (2000), ketahanan wilayah merupakan kondisi dinamik yang meliputi seluruh aspek kehidupan masyarakat, yang terintegrasi dalam menghadapi dan mengatasi segala macam tantangan, ancaman, hambatan serta gangguan baik yang datang dari dalam dan luar yang langsung maupun tidak langsung.

Lingkungan lahan gambut yang dapat dijaga dengan baik sesuai dengan fungsi dan peruntukannya merupakan salah satu kunci untuk mencapai ketahanan wilayah. Masyarakat dapat hidup dengan sejahtera dan makmur merasa aman dan nyaman tinggal di dalamnya tanpa takut ada bencana dan ancaman yang datang dari kondisi lahan gambut yang mengalami peralihan atau tidak sesuai dengan peruntukannya. Hal ini perlu diperhatikan dengan seksama dan tegas oleh para stakeholder dalam pengelolaan lahan gambut yang ada di DAS Kampar. Mengingat lahan gambut di DAS Kampar Provinsi Riau ini merupakan asset besar untuk mencapai ketahanan wilayah.

Lingkungan ekosistem lahan gambut DAS Kampar Provinsi Riau Sumatera salah satu komponen ketahanan wilayah di Provinsi Riau yang perlu dipertahankan. Menurut beberapa penelitian yang telah dilakukan sudah banyak terjadi kerusakan ekosistem lahan gambut yang membawa kepada bencana dan malapetaka. Tutupan hutan gambut di Provinsi Riau telah menurun dari $80 \%$ di tahun 1990 menjadi hanya lebih dari 36\% di tahun 2010 (Jauhianinen dkk, 2012).

Menurut PP Nomor 57 tahun 2016 tentang Perubahan atas PP Nomor 71 tahun 2014 tentang Perlindungan dan Pengelolaan Ekosistem Lahan Gambut bahwa ekosistem lahan gambut mempunyai fungsi lindung dan fungsi budidaya. Lahan gambut dengan kedalaman di atas 3 (tiga) meter masuk ke dalam kategori lindung. Oleh karena itu, tidak diperbolehkan untuk melakukan pembukaan tutupan lahan dan membuat drainase. Aktivitas pembukaan, pembersihan lahan dan pembuatan drainase (saluran) menyebabkan terjadinya perubahan tata air (Suwondo, dkk, 2010). Hal demikian memiliki pengaruh terhadap terjadinya tingkat kesuburan lahan gambut, penurunan muka tanah dan kering tidak balik (Las, dkk, 2008). Kondisi saat ini terlihat bahwa banyak lahan gambut dengan kedalaman di atas 3 (tiga) meter berubah menjadi perkebunan dan hutan tanaman industri (HTI) yang notabene merupakan tutupan lahan dengan vegetasi monogen (satu jenis).

Perubahan tutupan lahan gambut yang beralih fungsi menjadi lahan produktif menyebabkan lemahnya ketahanan lingkungan 
ekosistem lahan gambut. Seiring dengan melemahnya ketahanan lingkungan ekosistem lahan gambut, maka berdampak kepada masyarakat sekitar yang masuk ke dalam komponen lingkungan ekosistem lahan gambut. Pada akhirnya masyarakat mengalami bencana yang diakibatkan oleh kerusakan lahan gambut.

Kerusakan lahan gambut akan semakin luas dan berdampak besar jika pengelolaan lahan gambut dibiarkan sesuai dengan keinginan para pemilik kepentingan. Oleh karena itu, perlu dilakukan inventarisasi jenis-jenis alih fungsi lahan gambut di masingmasing kedalaman gambut akibat perbuatan manusia dan mengetahui sejauhmana ketahanan tutupan lahan gambut berupa biodiversitas vegetasi di DAS Kampar Provinsi Riau.

Alih fungsi lahan gambut di DAS Kampar Provinsi Riau Sumatera diperoleh dengan menggunakan metode survey dan transek plot. Metode survey digunakan untuk mengetahui kedalaman dan konversi

Tabel 1

Kedalaman Lahan Gambut Pada Masing-Masing Lokasi Sampel

Di DAS Kampar Provinsi Riau Sumatera.

\begin{tabular}{|c|c|c|c|}
\hline Kedalaman Gambut & Tipe Gambut & Lapisan Tanah Gambut & Lokasi Sampel \\
\hline $63-176 \mathrm{~cm}$ & Dangkal, Sedang & $\begin{array}{c}\text { Saprit } \\
\text { Liat Berdebu }\end{array}$ & Desa Subarak \\
\hline $163-185 \mathrm{~cm}$ & Sedang & $\begin{array}{c}\text { Saprit } \\
\text { Hemit } \\
\text { Liat berdebu } \\
\text { Liat Berpasir }\end{array}$ & Desa Lubuk Sakat \\
\hline $360-630 \mathrm{~cm}$ & Sangat Dalam & $\begin{array}{c}\text { Saprit } \\
\text { Hemik } \\
\text { Fibrik } \\
\text { Hemik } \\
\text { Liat berdebu }\end{array}$ & Desa Rantau Baru \\
\hline $160-220 \mathrm{~cm}$ & Sedang, Dalam & $\begin{array}{c}\text { Saprit } \\
\text { Hemit } \\
\text { Hemit } \\
\text { Fibrit } \\
\text { Hemit } \\
\text { Liat berdebu }\end{array}$ & Desa Kuala Terusan \\
\hline $405-425 \mathrm{~cm}$ & Sangat Dalam & $\begin{array}{c}\text { Saprit } \\
\text { Saprit } \\
\text { Saprit } \\
\text { Hemit } \\
\text { Fibrit } \\
\text { Liat berdebu }\end{array}$ & Desa Tanjung Punggai \\
\hline $47-215$ & Dangkal, Dalam & Saprit pasir & Desa Kutup \\
\hline $375-695$ & Sangat Dalam & $\begin{array}{c}\text { Saprit } \\
\text { Hemik } \\
\text { Fibrik } \\
\text { Liat berdebu }\end{array}$ & Desa Meranti \\
\hline $883-885 \mathrm{~cm}$ & Sangat Dalam & $\begin{array}{c}\text { Saprit } \\
\text { Fibrit } \\
\text { Hemik } \\
\text { Liat berdebu }\end{array}$ & Desa Sanggar \\
\hline
\end{tabular}

Sumber : Data Primer, 2017 
lahan gambut di lapangan berdasarkan tipe kedalaman lahan gambut. Metode transek plot digunakan untuk menghitung biodiversitas vegetasi. Masing-masing lokasi sampel dibuat 2 transek dan masing-masing transek dibuat 5 plot yang mewakili. Vegetasi yang dihitung berupa pohon yang mempunyai diameter di atas $6 \mathrm{~cm}$.

\section{PEMBAHASAN}

\section{Tipologi Lahan Gambut DAS Kampar}

Hasil penelitian kedalaman gambut pada delapan titik sampel menunjukkan bahwa lahan gambut di DAS Kampar Provinsi Riau Sumatera teridentifikasi masuk ke dalam kategori dangkal sampai dengan sangat dalam. Kedalaman gambut teridentifikasi berkisar dari $47 \mathrm{~cm}-883 \mathrm{~cm}$. Kedalaman gambut pada masing-masing lokasi sampel dapat dilihat pada tabel 1 .

Lahan gambut di DAS Kampar Provinsi Riau didominasi oleh lahan gambut dengan tipe sangat dalam. Hasil penelitian menunjukkan bahwa dari 8 lokasi sampel penelitian terdapat 4 lokasi sampel mempunyai kedalaman di atas tiga meter, artinya tipe kedalaman lahan gambut ini masuk dalam fungsi lindung ekosistem lahan gambut yang tidak boleh dilakukan pembukaan tutupan lahan dan pembuatan drainase yang dapat merubah pola aliran air. Tiga lokasi sampel lahan gambut sangat dalam berada di bagian hilir DAS Kampar dan satu lokasi sampel lahan gambut sangat dalam berada di bagian tengah DAS. Lokasi sampel lainnya masuk ke dalam kategori dangkal yang mempunyai kedalaman lahan gambut di bawah $100 \mathrm{~cm}$ terdapat di Desa Subarak dan Kutup, kategori sedang dengan kedalaman lahan gambut berkisar 100$200 \mathrm{~cm}$ berada di Desa Subarak, Lubuk Sakat dan Kuala Terusan dan tipe lahan gambut dalam tersebar di Desa Kuala Terusan dan Kutup.

Tanah gambut di seluruh lapisan atas lokasi sampel teridentifikasi mempunyai sifat saprit dengan tingkat kesuburan tinggi yang ditandai dengan hampir tidak terdeteksinya jaringan-jaringan tumbuhan. Berdasarkan tingkat kematangan gambut dapat dibedakan menjadi 3 yaitu (1). Gambut fibrik adalah lahan gambut yang masih tergolong mentah, kandungan bahan-bahan jaringan tanaman yang tinggi atau sisa-sisa tanaman yang masih dapat dilihat keadaan aslinya memiliki diameter antara $0,15 \mathrm{~cm}-2,00 \mathrm{~cm}$. Pada tipe ini perombakan yang dilakukan oleh mikro ogranisme masih sangat lambat sehingga masih tergolong miskin hara atau tidak subur, (2). Gambut hemik adalah lahan gambut yang sudah mengalami perombakan dan sifatnya separuh matang karena sudah banyak terjadi perombakan sisa-sisa tumbuhan oleh mikro organisme sehingga tipe ini masuk ke dalam kesuburan sedang, (3). Gambut saprik adalah lahan gambut yang sudah mengalami perombakan lanjut dan bersifat matang hingga sangat matang, perombakan yang dilakukan oleh mikroorganisme sudah hampir sempurna sampai sempurna sehingga tipe ini masuk ke dalam tipe subur dengan kandungan hara yang tinggi (Sukandarrumidi, 2008).

Penyebaran kedalaman lahan gambut di DAS Kampar Provinsi Riau Sumatera ini tidak merata. Kondisi lahan gambut dengan kedalaman di atas 3 meter sangat banyak dijumpai pada bagian hilir DAS Kampar, bahkan kedalaman gambut di hilir ini teridentifikasi mencapai kedalaman 15 meter. Seperti yang terlihat pada peta sebaran kedalaman gambut yang tertera di Kantor Desa Meranti Kabupaten Pelalawan. Beberapa penelitian telah dilakukan oleh para 
ilmuan terdahulu di sekitar Meranti, hasilnya menunjukkan bahwa kedalaman gambut di daerah tersebut merupakan tipe lahan gambut sangat dalam. Peta tipologi lahan gambut di DAS Kampar Provinsi Riau Sumatera dapat dilihat pada gambar 2 .

Dari peta tipologi lahan gambut di DAS Kampar terlihat bahwa sebaran lahan gambut paling dominan berada di hilir DAS Kampar Provinsi Riau Sumatera. Lahan gambut yang ada di hilir DAS di dominasi oleh tipe lahan dengan kategori sangat dalam. Riau mempunyai lapisan gambut terdalam di dunia, yaitu mencapai 16 meter terutama di wilayah Kuala Kampar (Anonimous, 2006). Menurut Peraturan Pemerintah Nomor 71 tahun 2014 tentang Perlindungan Dan Pengelolaan Ekosistem Lahan Gambut, bahwa lahan gambut yang mempunyai kedalaman di atas 3 meter masuk ke dalam kategori lindung, yang tidak boleh dilakukan pembukaan tutupan lahan dan tidak diperkenankan untuk membuat drainase. Diperkirakan dengan adanya perubahan tutupan lahan dan pembuatan drainase mengakibatkan kerusakan pada lahan gambut yang terbentuk dengan waktu yang sangat lama dan sangat rentan terhadap kerusakan yang tidak dapat balik ke bentuk semula.

Hal ini menunjukkan bahwa di masa lampau ketahanan lingkungan lahan gambut sangat terjaga. Artinya belum terdapat campur tangan manusia dalam pengelolaan lahan gambut yang dapat menyebabkan kerusakan signifikan. Kegiatan yang dilakukan oleh masyarakat sekedar untuk pemenuhan kebutuhan saja. Oleh karena itu kegiatan tersebut masih dapat dinetralkan kembali oleh lingkungan secara alami. Lingkungan masih mempunyai ketahanan yang sangat kuat dan besar, sehingga mampu mengembalikan perubahan yang dilakukan ke bentuk semula.

Gambar 2

Peta Tipologi Lahan Gambut Di DAS Kampar Provinsi Riau Sumatera

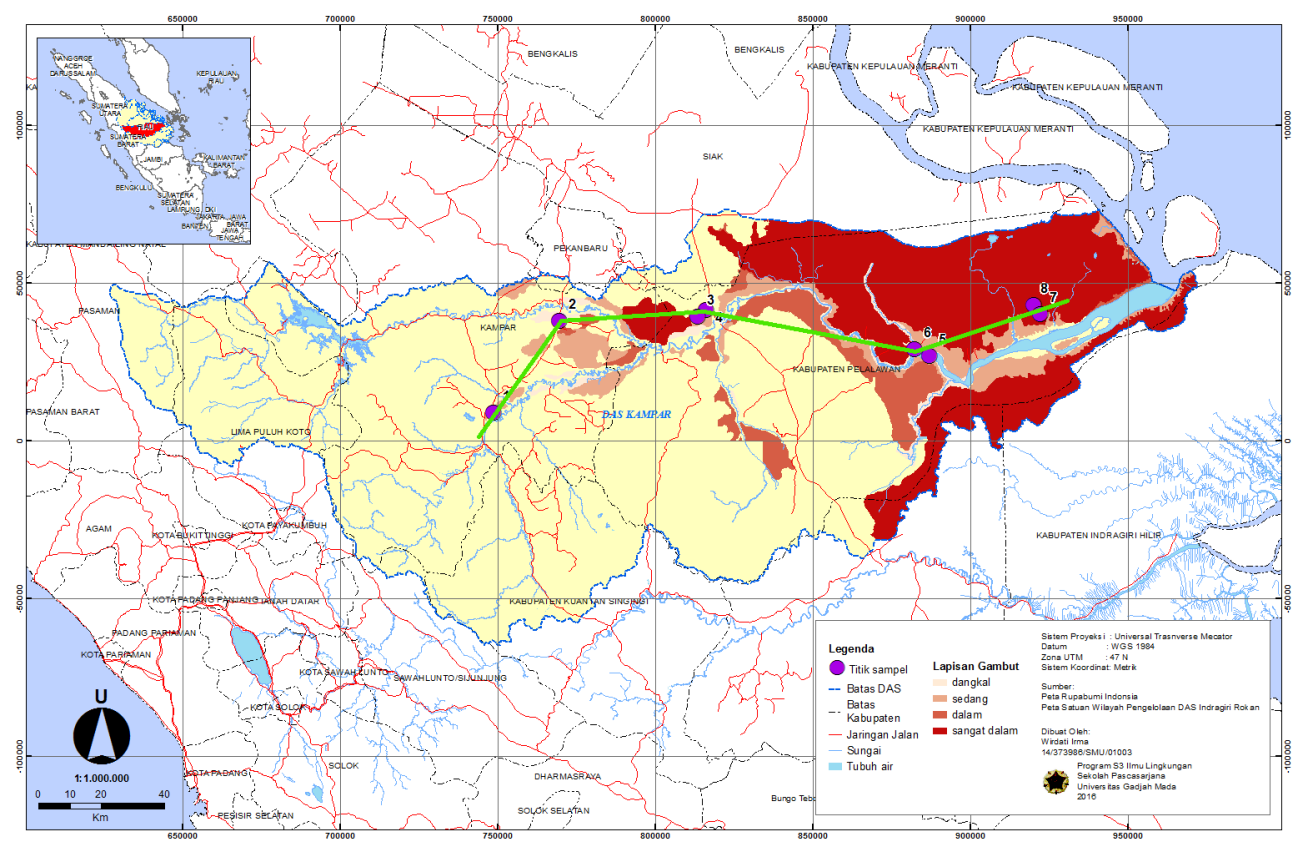

Sumber : Gambar Primer, 2018 
Ketahanan lingkungan yang tercipta dapat menjadi daya dukung dalam pemenuhan kebutuhan hidup pada ekosistem lahan gambut. Kawasan Semenanjung Kampar yang masuk ke dalam DAS Kampar merupakan salah satu hamparan lahan gambut terluas yang terletak di Provinsi Riau. Semenanjung Kampar berada di hilir DAS Kampar mempunyai ekosistem hutan gambut yang terletak di antara dua sungai besar, yakni Sungai Siak dan Sungai Kampar. Kondisi sebagian besar kawasan Semenanjung Kampar merupakan lahan gambut dengan tipe kubah gambut besar (peat dome). Rata-rata lahan gambut di kawasan ini didominasi oleh kedalaman gambut dalam hingga sangat dalam dan beberapa kubah gambut kecil (Qomar dan Jaya, 2010).

\section{Konversi Lahan Gambut di DAS Kampar}

Seiring berjalannya waktu dan pertambahan penduduk, maka bertambah pula kebutuhan yang harus dipenuhi. Pemenuhan kebutuhan sandang, pangan dan papan membuat kebutuhan lahan semakin meningkat, karena ketiga hal tersebut merupakan kebutuhan dasar dan pokok manusia. Lahan gambut menjadi salah satu lahan alternatif yang menjadi sasaran dimanfaatkan untuk pemenuhan kebutuhan tersebut. Kondisi demikian menyebabkan lahan gambut mengalami konversi sesuai kebutuhan yang diinginkan, yang pada akhirnya dapat menurunkan ketahanan lingkungan. Hal ini menjadi ancaman bagi ekosistem lingkungan lahan gambut yang mengakibatkan kerentanan terhadap bencana yang secara tidak langsung akan menghancurkan ketahanan lingkunan lahan gambut.

Hasil penelitian pada 8 lokasi sampel menunjukkan bahwa kondisi lahan gambut mengalami konversi lahan. Konversi lahan yang terjadi berupa perkebunan kelapa sawit, karet, hutan tanaman industri dan perumahan. Ditemukan hanya 1 (satu) lokasi dari 8 lokasi sampel teridentifikasi sebagai hutan primer yang masih mempunyai biodiversitas vegetasi.

Gambar 3

Profil Tutupan Lahan Gambut Di DAS Kampar Provinsi Riau Sumatera

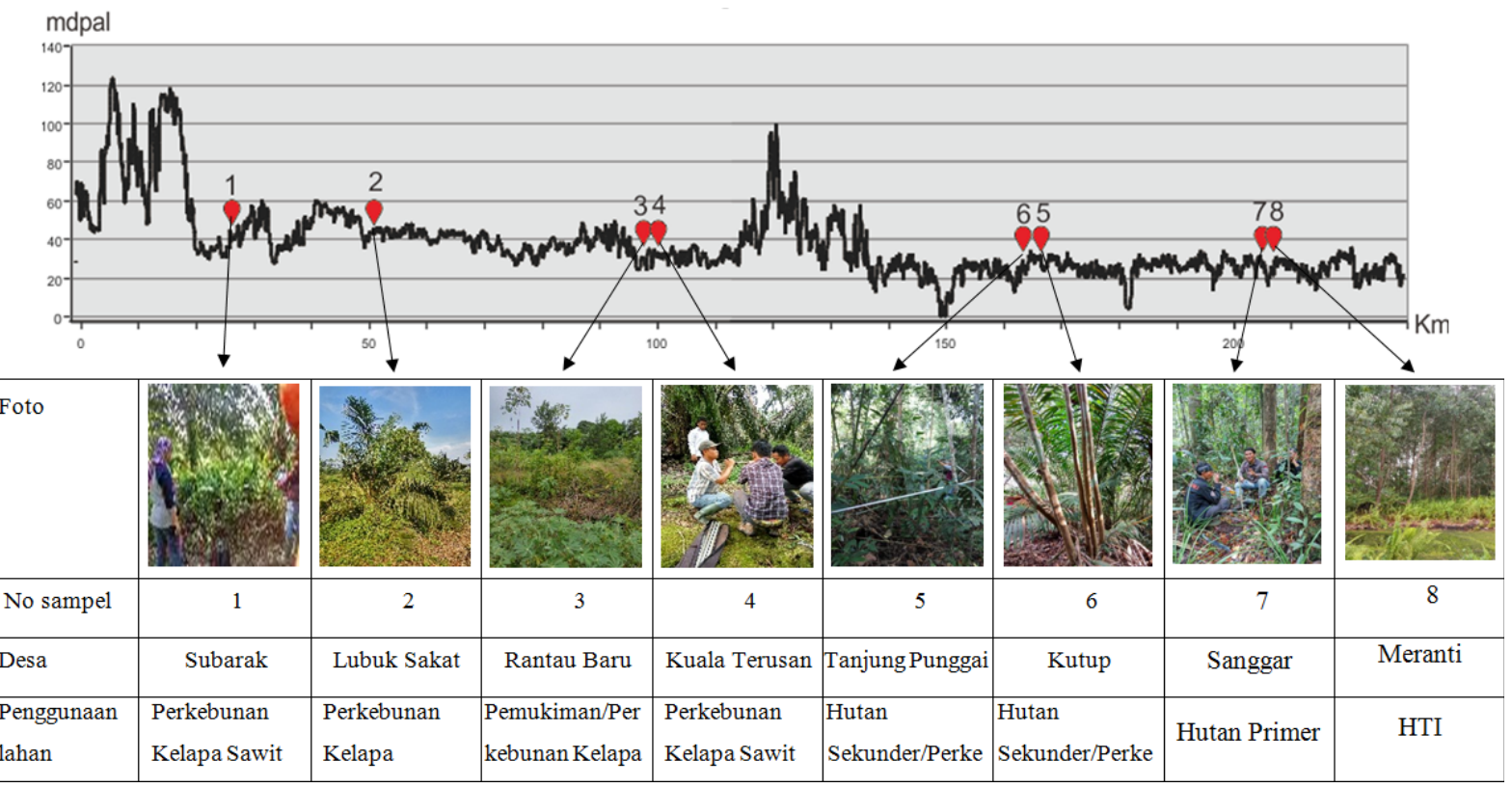

Sumber : Gambar primer, 2017 
Tujuh lokasi sampel sudah mengalami konversi lahan gambut menjadi lahan produktif untuk menunjang pemenuhan kebutuhan hidup masyarakat. Kondisi ini dapat dilihat dari profil gambar 3.

Gambar profil tutupan lahan gambut di DAS Kampar Provinsi Riau Sumatera teridentifikasi menjadi beberapa bentuk, sebagai berikut.

Pertama, Desa Subarak teridentifikasi sebagai perkebunan kelapa sawit yang diusahakan oleh perusahaan dengan umur 10 tahun dalam masa produktif.

Kedua, Desa Lubuk Sakat termasuk satu kabupaten dengan Desa Subarak yaitu Kabupaten Kampar dengan tutupan lahan sebagai perkebunan kelapa sawit baik yang diusahakan oleh perusahaan maupun masyarakat setempat dan permukiman penduduk. Desa Lubuk Sakat ini masuk ke dalam kawasan jalan lintas Sumatera sehingga sudah mulai banyak terdapat pemukiman penduduk. Perkebunan kepala sawit masyatakat lebih banyak terdapat sepanjang pinggir jalan lintas Sumatera bercampur dengan pemukiman. Perkebunan kelapa sawit perusahaan lebih ke dalam dari jalan lintas Sumatera bisa dikatakan tidak terdapat pemukiman penduduk di dalam kawasan perkebunan perusahaan ini.

Ketiga, Desa Rantau Baru, Kabupaten Pelalawan, merupakan kawasan pemekaran desa baru yang tadinya berada agak ke dalam dari belahan Sungai Kampar. Lokasi ini tadinya merupakan kawasan perkebunan kelapa sawit, lahan gambut kritis yang tidak dimanfaatkan karena faktor alam yang tidak memungkinkan untuk dimanfaatkan sehingga seperti lahan gambut yang ditinggalkan begitu saja. Mengingat kawasan ini terjadi pemekaran wilayah maka saat ini Desa Rantau
Baru teridentifikasi tutupan lahannya berupa perkebunan kelapa sawit, pemukiman dan lahan gambut kritis yang tidak dimanfaatkan dan tidak ditumbuhi oleh tumbuhan endemik lahan gambut.

Keempat, Desa Kuala Terusan teridentifikasi sebagai kawasan dengan tutupan lahan sebagai perkebunan kelapa sawit yang di usahakan oleh perusahaan dengan umur di atas 13 tahun, namun tidak terurus dengan baik.

Kelima, Desa Tanjung Punggai merupakan kawasan lahan gambut yang teridentifikasi sebagai perkebunan kelapa sawit, karet, dan hutan sekunder/semak belukar. Pada kawasan ini perkebunan kelapa sawit dan karet diusahakan oleh masyarakat seberang dari lokasi lahan gambut Desa Tanjung Punggai. Menurut masyarakat pemilik perkebunan mengatakan bahwa perkebunan karet merupakan perkebunan turun temurun dari tetua mereka dahulu yang tetap mereka pertahankan keberadaannya.

Keenam, Desa Kutup merupakan desa yang berada bersebelahan dengan Desa Tanjung Punggai dan kondisi tutupan lahannya hampir sama dengan Desa Tanjung Punggai, yakni berupa perkebunan kelapa sawit, karet, hutan sekunder/semak belukar dan permukiman, namun pemukiman yang ada hanya pemukiman sementara para pekerja perkebunan.

Ketujuh, Desa Sanggar yang berada hampir dekat dengan perbatasan laut dan berada di Kecamatan Pulau Muda, teridentifikasi tutupan lahannya masih alami dengan tipe hutan primer yang masih banyak dijumpai tumbuhan endemik lahan gambut. Seiring berjalanannya waktu dan penambahan jumlah penduduk, hutan primer sudah mulai mengalami kerusakan dengan adanya penebangan secara liar. 
Kedelapan, Desa Meranti tutupan lahan gambut teridentifikasi sebagai hutan tanaman industri dengan variasi umur tanaman akasia (Acasia casicarpa), bahkan ada yang masih dalam tahapan pembersihan lahan untuk dilakukan penanaman kembali.

Pembukaan lahan gambut untuk tanaman produksi menyebabkan jenis-jenis vegetasi khas lahan gambut tidak dapat ditemukan. Jenis-jenis vegetasi yang ada hanya jenis vegetasi produksi perkebunan dan hutan tanaman industri guna memperoleh produksi maksimal. Seluruh lahan gambut yang dijadikan perkebunan dan hutan tanaman industri tidak menyisakan lahan gambut untuk tumbuhnya jenis vegetasi lain. Kekhawatiran dengan kondisi ini semakin menyudutkan untuk mencapai ketahanan lingkungan yang selanjutnya mengancam terhadap ketahanan wilayah khususnya lahan gambut yang ada di DAS Kampar. Konversi yang menyebabkan perubahan fungsi dari lahan gambut dapat menghambat kestabilan dan menurunkan daya dukung lingkungan. Jika tidak dibenahi dan dilakukan restorasi menyebabkan kerusakan lingkungan semakin parah.

\section{Biodiversitas Vegetasi Lahan Gambut DAS Kampar}

Konversi lahan gambut menjadi lahan perkebunan dan HTI menyebabkan banyak masyarakat yang ada di lahan gambut DAS Kampar merasa mengalami ancaman pada perekonomian, sandang dan pangan, mengingat perkebunan dan HTI yang diciptakan tidak dapat dinikmati oleh seluruh masyarakat. Hanya mereka yang mempunyai kekuasaan dan perekonomian yang kuat yang dapat merasakan manfaatnya. Berbeda dengan fungsi alami yang diperoleh masyarakat dengan kondisi lahan gambut masih alami, semua masyarakat dapat menikmati dan merasakannya, karena siapa saja dapat mengambil manfaat dari lahan gambut asal tidak melebihi kapasitas pemulihan alami oleh lingkungan lahan gambut.

Kondisi konversi lahan gambut yang saat ini sudah terjadi mengakibatkan penurunan jenis vegetasi. Masyarakat tidak dapat lagi menikmati seperti sayur dari rotan yang dapat diambil bebas di dalam hutan lahan gambut. Kayu untuk tiang rumah yang biasa dapat diambil sesuai kebutuhan untuk pembuatan rumah sudah berganti dengan tanaman kelapa sawit, karet dan akasia. Jika masyarakat ingin membuat rumah, fasilitas umum harus membeli kayu. Banyak hal lain yang tidak dapat dirasakan dan dinikmati lagi oleh masyarakat pada umumnya setelah konversi lahan gambut ini terjadi. Akibat yang nyata adalah terjadinya penurunan biodiversitas vegetasi yang menjadi salah satu komponen ketahanan lingkungan di dalam wilayah DAS Kampar. Jenis vegetasi yang terdapat di lokasi penelitian dapat dilihat pada tabel 2 .

Jenis vegetasi yang ditemukan di lokasi sampel penelitian berjumlah 50 jenis dengan total jumlah individu sebanyak 4478 dengan pola penyebaran jenis-jenis vegetasi tidak merata. Masing-masing lokasi ada yang hanya dijumpai 1 jenis vegetasi dengan jumlah individu di atas 1000. Hal ini menunjukkan di lokasi tersebut vegetasi yang terbentuk hasil buatan manusia berupa perkebunan maupun hutan tanaman industri yang sengaja dibentuk seragam vegetasi yang tumbuh menjadi tutupan lahannya. Kondisi ini bertujuan untuk memenuhi target produksi dalam peningkatan perekonomian. Perkebunan dan hutan tanaman industri yang terbentuk melalui pembukaan lahan gambut yang asli terlebih dahulu untuk menciptakan vegetasi 
Tebel 2

Jenis-Jenis Vegetasi Yang Terdapat Di Masing-Masing Lokasi Penelitian DAS Kampar Provinsi Riau Sumatera

\begin{tabular}{|c|c|c|c|c|c|c|c|c|c|c|}
\hline \multirow{2}{*}{ No } & \multirow{2}{*}{ Spesies } & \multicolumn{8}{|c|}{ Stasiun Penelitian (ST) } & \multirow{2}{*}{ Jumlah } \\
\hline & & 1 & 2 & 3 & 4 & 5 & 6 & 7 & 8 & \\
\hline 1 & Acasia casicarpa & & & & & $\mathrm{V}$ & $\mathrm{V}$ & & $\mathrm{V}$ & 1153 \\
\hline 2 & Cerbera manghas L. & $\mathrm{V}$ & & & & & $\mathrm{V}$ & & & 7 \\
\hline 3 & Ficus pumnila & & & & & & $\mathrm{V}$ & $\mathrm{V}$ & & 2 \\
\hline 4 & Diospyros sp & & & & & $\mathrm{V}$ & $\mathrm{V}$ & $\mathrm{V}$ & & 37 \\
\hline 5 & Ficus carica & & & & & $\mathrm{V}$ & $\mathrm{V}$ & & & 3 \\
\hline 6 & Palaquium qutta* & & & & & & & $\mathrm{V}$ & & 33 \\
\hline 7 & Catalina brachiata & & & & & & & $\mathrm{V}$ & & 22 \\
\hline 8 & Cratoxylon arborescen & & & & & & & $\mathrm{V}$ & & 4 \\
\hline 9 & Cinnamomum $s p$ & & & & & & & $\mathrm{~V}$ & & 99 \\
\hline 10 & Sterculia foetida & & & & & & & $\mathrm{V}$ & & 3 \\
\hline 11 & Citrus sp. & $\mathrm{V}$ & & & & & & & & 1 \\
\hline 12 & Garcinia dioica & & & & & $\mathrm{V}$ & & & & 5 \\
\hline 13 & Ficus elastica & & & & & & $\mathrm{V}$ & & & 338 \\
\hline 14 & Coccus nucifera & $\mathrm{V}$ & & & & & & & & 1 \\
\hline 15 & Alaeis quineensis & $\mathrm{V}$ & $\mathrm{V}$ & $\mathrm{V}$ & $\mathrm{V}$ & & $\mathrm{V}$ & & & 1449 \\
\hline 16 & Syzyqium sp.* & & & & & $\mathrm{V}$ & & V & & 46 \\
\hline 17 & Lusuma malaccensis* & & & & & & & $\mathrm{V}$ & & 37 \\
\hline 18 & Eleidoxa conferta & & & & & $\mathrm{V}$ & $\mathrm{V}$ & & & 57 \\
\hline 19 & Macaranga javanica & & & & & $\mathrm{V}$ & $\mathrm{V}$ & & & 13 \\
\hline 20 & Parastemon urophyllus* & & & & & & & $\mathrm{V}$ & & 20 \\
\hline 21 & Mangifera indica & $\mathrm{V}$ & & $\mathrm{V}$ & & & $\mathrm{V}$ & $\mathrm{V}$ & & 216 \\
\hline 22 & Gracinia rostrata & & & & & & & $\mathrm{V}$ & & 30 \\
\hline 23 & Pometia pinnata & $\mathrm{V}$ & & & & & & & & 1 \\
\hline 24 & Cinnamomun blurne* & & & & & $\mathrm{V}$ & $\mathrm{V}$ & $\mathrm{V}$ & & 14 \\
\hline 25 & Myristica iners* & & & & & & & $\mathrm{V}$ & & 57 \\
\hline 26 & Callophylum saulattri* & & & & & $\mathrm{V}$ & $\mathrm{V}$ & $\mathrm{V}$ & & 98 \\
\hline 27 & Shorea platyclados* & & & & & $\mathrm{V}$ & $\mathrm{V}$ & $\mathrm{V}$ & & 40 \\
\hline 28 & Shore leprosula* & & & & & $\mathrm{V}$ & $\mathrm{V}$ & $\mathrm{V}$ & & 113 \\
\hline 29 & Arthocarpus emando & & & & & $\mathrm{V}$ & $\mathrm{V}$ & & & 12 \\
\hline 30 & Pandanus teriorius & & & $\mathrm{V}$ & & $\mathrm{V}$ & & $\mathrm{V}$ & & 38 \\
\hline 31 & Hevea bransiliensis* & & & & & $\mathrm{V}$ & & $\mathrm{V}$ & & 16 \\
\hline 32 & Stemonurussecundiflorus & & & & & & & $\mathrm{V}$ & & 140 \\
\hline 33 & Tristaniopsis sp* & & & & & & & $\mathrm{V}$ & & 35 \\
\hline 34 & Areca catechu & & & $\mathrm{V}$ & & & $\mathrm{V}$ & & & 9 \\
\hline 35 & Areca vestiaria & & & & & & & $\mathrm{V}$ & & 11 \\
\hline 36 & Musa paradisiaca & $\mathrm{V}$ & & $\mathrm{V}$ & & & & & & 13 \\
\hline 37 & Tetramerista glabra* & & & & & $\mathrm{V}$ & $\mathrm{V}$ & $\mathrm{V}$ & & 63 \\
\hline 38 & Nephelium lappaceum & $\mathrm{V}$ & & & & & & & & 2 \\
\hline 39 & Benstonea affinis & & & & & $\mathrm{V}$ & $\mathrm{V}$ & $\mathrm{V}$ & & 11 \\
\hline 40 & Gluta rengas* & & & & & $\mathrm{V}$ & $\mathrm{V}$ & & & 16 \\
\hline 41 & Calamus axillaris & & & & & $\mathrm{V}$ & $\mathrm{V}$ & & & 8 \\
\hline 42 & Melastom candidum & & & $\mathrm{V}$ & & & & & & 18 \\
\hline 43 & Palaquiumwalsurifolium* & & & & & $\mathrm{V}$ & $\mathrm{V}$ & $\mathrm{V}$ & & 4 \\
\hline 44 & Campnospermaauriculata* & & & & & $\mathrm{V}$ & $\mathrm{V}$ & $\mathrm{V}$ & & 36 \\
\hline & Euodia redleyi & & & & & & & & & \\
\hline 45 & Planconella nitida & & & $\mathrm{V}$ & & & & $\mathrm{V}$ & & 24 \\
\hline 46 & Ilex cymosa & & & & & & & $\mathrm{V}$ & & 2 \\
\hline 47 & Manihot utilisima & & & & & & & & & 2 \\
\hline 48 & Malabatricum sp. & & & $\mathrm{V}$ & & & & $\mathrm{V}$ & & 9 \\
\hline 49 & Hibiscus tiliaceus & & & & & & & & & 84 \\
\hline 50 & & & & $\mathrm{~V}$ & & & & & & 20 \\
\hline & Jumlah Total & & & & & & & & & 4478 \\
\hline
\end{tabular}

Sumber : Data primer, 2017.

(Keterangan; * = Dilindungi. 1) Desa Lubuk Sakat, 2) Desa Subarak, 3) Desa Rantau Baru, 4) Desa Kuala Terusan, 5) Desa Tanjung Punggai, 6) Desa Kutup, 7) Desa Sanggar, dan 8) Desa Meranti. 
yang homogen, selain pembukaan lahan yang dilakukan juga membuat drainase guna mobilitas perkebunan dan hutan tanaman industri. Proses yang dilakukan menyebabkan ketahanan lingkungan menjadi terganggu bahkan sampai merusak.

Lokasi Desa Sanggar merupakan lokasi dengan jumlah jenis vegetasi terbanyak yang dijumpai dari delapan lokasi sampel penelitian, yaitu sebanyak 30 jenis dan 1156 total individu dari 50 jenis yang ditemukan di seluruh lokasi penelitian. Lokasi ini merupakan lokasi hutan primer lahan gambut yang memang dipertahankan keberadaan dan kelestariannya oleh masyarakat, tokoh adat dan perusahaan yang ada di sekitarnya. Lokasi yang lain seperti Desa Tanjung Punggai, Kutup, Rantau Baru dan Lubuk Sakat masih mempunyai beberapa jenis vegetasi di dalamnya. Penelitian yang dilakukan oleh Lisdayanti dkk (2016), menyatakan bahwa jumlah jenis vegetasi yang dijumpai di hutan rawa musiman Rimbo Tujuh Danau Riau pada semua tingkatan sebanyak 97 jenis, namun yang berhasil bertahan sampai pada tingkat pohon hanya 25 jenis saja. Hasil penelitian Djufri (2013), ditemukan 31 jenis spesies di kawasan Rawa Tripa Aceh Barat.

Lahan gambut yang mengalami konversi jenis vegetasi yang tumbuh hanya sejenis saja, karena lahan ini diusahakan untuk meningkatkan produktivitas perekonomian. Seperti jenis vegetasi kelapa sawit, karet dan akasia yang menjadi produk unggulan usaha perekonomian masyarakat maupun perusahaan. Area yang diusahakan menjadi lahan produktif untuk perkebunan dan hutan tanaman industri ini diusahakan tidak ada jenis lain yang hidup berdampingan agar produktivitasnya optimal. Kondisi ini menyebabkan rantai dan jaring-jaring makanan yang harusnya mempunyai daur panjang menjadi pendek dan singkat sehingga energi yang mengalir juga berlangsung cepat. Perubahan yang terjadi menyebabkan pola interaksi baik antar sesama jenis, interaksi antar jenis yang lain, dan interaksi dengan lingkungan tidak stabil dan timpang. Kestabilan lingkungan menjadi ketahanan lingkungan bagi kehidupan di satu kawasan, ketahanan lingkungan yang tidak didukung oleh daya dukung lingkungan yang diperlukan oleh unsur komponen lingkungan menjadi ambang kehancuran bagi suatu lingkungan tersebut.

Sedikitnya jenis-jenis vegetasi yang ada di lahan gambut menyebabkan unsur biotik lain berupa fauna migrasi ketempat lain mencari tempat yang aman dan mendukung habitat mereka. Seperti tidak dijumpai lagi adanya hewan-hewan mamalia yang biasa hidup di dalam hutan dengan biodiversitas vegetasi tinggi. Pembukaan lahan yang dilakukan menyebabkan hewan-hewan kehilangan sumber makanan dan tempat tinggal mereka. Kondisi ini sangat tidak menguntungkan bagi kawanan hewan yang biasa hidup bebas di dalam hutan dengan sumber makanan yang cukup dan tempat tinggal yang aman dan nyaman. Situasi ini menciptakan dua pilihan bagi kawanan hewan yang ada, yaitu (1). Bertahan hidup dengan kondisi yang serba tidak tersedia bahkan harus bertarung dengan mempertaruhkan nyawa untuk mendapatkan makanan dan tempat tinggal dengan yang lainnya, atau (2). Pindah dan mengungsi ke tempat lain mencari lokasi baru yang menjanjikan bagi pemenuhan makanan dan tempat tinggal.

Kedua pilihan yang tercipta tersebut samasama berat dan penuh resiko dan tantangan bagi hewan-hewan ini. Jika hewan-hewan yang tetap tinggal tidak dapat bertahan hidup maka 
lama-kelamaan hewan-hewan ini akan mati dan punah, demikian juga dengan hewan-hewan yang memilih pilihan kedua dengan mencari tempat baru sebagai tempat mereka hidup. Jika tidak sesuai dengan kebutuhan yang mereka perlukan dan tidak aman bagi kehidupan mereka, maka lambat laun kematian dan kepunahan akan mereka alami.

Kepunahan dan kematian yang dialami oleh hewan-hewan lahan gambut di DAS Kampar Provinsi Riau Sumatera ini berawal dari perubahan tutupan lahan yang dilakukan oleh manusia untuk memenuhi kebutuhan hidup yang melemahkan ketahanan lingkungan. Komposisi dan struktur vegetasi dapat menjadi bahan penilaian ketahanan lingkungan di lahan gambut. Penghitungan nilai komposisi dan struktur vegetasi ini dapat menggambarkan kondisi vegetasi yang ada di suatu lokasi, sehingga dapat disimpulkan ketahanan lingkungannya. Komposisi dan struktur vegetasi diperoleh dari kerapatan, dominansi dan frekuensi. Kawasan yang mempuyai nilai kerapatan, dominansi dan frekuensi tinggi biasanya mempunyai indeks nilai penting (INP) tinggi. Komposisi dan struktur vegetasi lahan gambut di DAS Kampar Provinsi Riau Sumatera ini dapat di lihat pada tabel 3.
Tabel 3 menunjukkan indeks nilai penting yang tertinggi dengan nilai kerapatan tinggi, dominansi tinggi dan frekuensi tinggi terdapat di Desa Sanggar. Artinya di Desa Sanggar ini masih mempunyai komposisi dan struktur vegetasi merata di lahan gambut, sementara dominasi paling tinggi berada di Desa Kuala Terusan, namun jumlah jenis vegetasinya hanya sejenis saja karena di lokasi ini merupakan kawasan konsesi perkebunan kelapa sawit yang diusahakan oleh perusahaan. Lahan gambut dengan tingkat dominansi tinggi dengan tidak mempunyai nilai biodiversitas vegetasi dapat menjadi penyebab terjadinya penurunan ketahanan lingkungan. Ketahanan lingkungan berupa komponen biotik, abiotik yang dibutuhkan oleh lahan gambut tidak dapat berjalan dengan optimal di dalam ekosistem lahan gambut. Interaksi yang berlangsung tidak menggambarkan interaksi kompleks yang dibutuhkan untuk kestabilan lingkungan guna mencapai ketahanan lingkungan. Seperti di Desa Kuala Terusan hanya terdapat vegetasi sejenis yaitu kelapa sawit. Menurut Holidi dkk (2013), bahwa kelapa sawit tidak cocok pada lahan gambut mengingat kelapa sawit dapat bertahan hidup dengan genangan hanya selama 50 hari karena lama genangan dapat menghambat pertumbuhan dari kelapa sawit.

Tabel 3

Komposisi Dan Struktur Vegetasi Lahan Gambut Di DAS Kampar Provinsi Riau Sumatera

\begin{tabular}{ccccccc}
\hline No & Stasiun pengamatan & Jumlah Jenis & Jumlah Spesies & K & D & F \\
\hline 1 & Lubuk Sakat & 9 & 379 & 0,01516 & 0,016600 & 1,8 \\
2 & Subarak & 1 & 360 & 0,00144 & 0,19150516 & 1 \\
3 & Ranatau Baru & 10 & 333 & 0,01332 & 0,11524201 & 3,1 \\
4 & Kuala Terusan & 1 & 360 & 0,0144 & 0,28311212 & 1 \\
5 & Tanjung Punggai & 20 & 231 & 0,00924 & 0,046073856 & 11,2 \\
6 & Kutup & 22 & 540 & 0,0216 & 0,108087906 & 4,6 \\
7 & Sanggar & 30 & 1156 & 0,04624 & 0,191496355 & 18,3 \\
8 & Meranti & 1 & 1120 & 0,0448 & 0,08615248 & 1 \\
\hline
\end{tabular}

Sumber ; Data primer, 2017

(Keterangan : $\mathrm{K}=$ Kerapatan, $\mathrm{D}=$ Dominansi, $\mathrm{F}=$ Frekuensi) 
Biodiversitas yang tercipta di hutan primer Desa Sanggar DAS Kampar Provinsi Riau Sumatera menunjukkan bahwa di lokasi tersebut mempunyai tingkat ketahanan lingkungan yang tinggi dibandingkan dengan 7 lokasi sampel lainnya, karena banyak komponen lingkungan yang ada di dalamnya masih stabil dan seimbang. Aliran energi yang berlangsung berjalan lebih panjang dan kompleks dibandingkan dengan lokasilokasi yang hanya mempunyai tutupan lahan sejenis saja. Biodiversitas vegetasi yang tinggi membentuk ekosistem yang seimbang karena mempunyai daya dukung lingkungan yang optimal untuk menunjang kehidupan komponen biotik yang ada di dalamnya. Di Desa Sanggar terdapat banyak jenis hewan-hewan yang hidup di dalamnya, karena banyak sumber makanan dan tempat tinggal yang nyaman yang mereka dapati. Jika biodiversitas vegetasi dan hewan dapat dijumpai di dalam hutan primer Desa Sanggar ini, maka kehidupan yang lain seperti mikro organisme juga dapat hidup dengan baik. Komponen abiotik yang tercipta dengan keberadaan biodiversitas vegetasi dan hewan dapat optimal. Jika komponen biotik dan abiotik dalam suatu ekosistem lingkungan lahan gambut berjalan dengan seimbang, maka ketahanan lingkungan lahan gambut dapat berlangsung dengan aman dan nyaman.

Banyaknya jumlah individu satu jenis vegetasi yang tumbuh di lahan gambut belum tentu dapat menyediakan kebutuhan ketahanan lingkungan seperti banyaknya jumlah jenis vegetasi di dalam ekosistemnya. Interaksi yang terjalin antar komponen lingkungan hanya searah, tidak sesuai dengan yang dibutuhkan oleh seluruh komponen lingkungan yang ada di dalamnya. Oleh karenanya banyak unsur komponen lingkungan yang tidak dapat survive dilahan yang sudah dikonversi menjadi perkebunan ini. Hal ini menyebabkan beberapa unsur komponen biotik lingkungan seperti hewan mencari tempat lain untuk memperoleh ketahanan lingkungan yang menjadi daya dukung kebutuhan untuk dapat tetap bertahan hidup. Bahkan ada yang sudah mati tidak dapat bertahan hidup seperti komponen biotik lainnya berupa tumbuhan, hewan-hewan yang rentan terhadap keseimbangan alam dan mikro organisme.

Pindah atau migrasinya hewan-hewan ini karena tidak ada lagi makanan yang dapat mereka peroleh di lokasi tersebut. Makanan yang biasanya mereka dapati dari berbagai jenis vegetasi yang tumbuh di lahan gambut sudah tidak lagi mereka jumpai, sehingga hewan-hewan tersebut harus mencari makanannya ke tempat lain yang dapat mendukung kehidupan mereka. Akibat menurun dan hilangnya ketahanan lingkungan di lahan gambut maka hewan-hewan yang biasanya tinggal di dalamnya harus mencari tempat lainnya untuk dapat survive. Bahkan tidak sedikit hewan-hewan buas yang ada di lahan gambut masuk ke pemukiman penduduk karena terancamnya habitat tempat mereka bernaung.

Kegiatan konversi lahan gambut yang dilakukan mengakibatkan biodiversitas vegetasi banyak yang hilang. Indeks biodiversitas vegetasi yang tadinya mempunyai nilai tinggi mengalami penurunan, bahkan banyak yang tidak mempunyai biodiversitas vegetasi. Hal ini disebabkan akibat ditanami tanaman sejenis yang produktif dan mempunyai nilai ekonomi tinggi. Perkebunan kelapa sawit, karet dan hutan tanaman industri yang dibangun oleh masyarakat maupun perusahaan menyebabkan jenis-jenis tumbuhan lahan gambut jarang dan tidak ditemukan. Hilangnya biodiversitas vegetasi menyebabkan lahan 
Tabel 4

\begin{tabular}{lcc}
\multicolumn{2}{l}{ Indeks Biodiversitas Vegetasi Lahan Gambut Di DAS Kampar Provinsi Riau Sumatera. } \\
\hline Lokasi sampel & Jumlah jenis vegetasi & $\begin{array}{l}\text { Nilai Indeks Biodiversitas } \\
\text { vegetasi (H') }\end{array}$ \\
\hline Subarak & 1 & 0 \\
Lubuk Sakat & 9 & 0,292 \\
Rantau Baru & 10 & 1,294 \\
Kuala Terusan & 1 & 0 \\
Tanjung Punggai & 20 & 2,53 \\
Kutup & 22 & 1,189 \\
Meranti & 1 & 0 \\
Sanggar & 30 & 2,83 \\
\hline
\end{tabular}

Sumber : Data Primer, 2017

gambut mengalami penurunan dan kerusakan. Fungsi lahan gambut sebagai ekologi sudah tidak dapat diperoleh lagi, sehingga menimbulkan hilangnya ketahanan lingkungan lahan gambut, dan menyebabkan lingkungan lahan gambut mengalami kerusakan bahkan dapat menyebabkan kehancuran. Nilai indeks biodiversitas vegetasi lahan gambut pada masing-masing sampel yang dihitung menggunakan rumus Shannon Wienner dapat dilihat pada tabel 4 .

Nilai Indeks Biodiversitas vegetasi yang ada di lahan gambut DAS Kampar masuk ke dalam kategori rendah sampai dengan sedang. Kategori ini berdasarkan kriteria Shannon Wienner, yaitu apabila H'>3 kategori biodiversitas tinggi, penyebaran jumlah individu tiap spesies tinggi dan kestabilan komunitas tinggi, apabila H'1-3 kategori biodiversitas sedang, penyebaran jumlah individu tiap spesies sedang dan kestabilan komunitas sedang, dan $\mathrm{H}^{\prime}<1$ kategori biodiversitas rendah, penyebaran jumlah individu tiap spesies rendah dan kestabilan komunitas rendah.

Lahan gambut di DAS Kampar Provinsi Riau Sumatera terdapat 3 (tiga) lokasi yang mempunyai nilai indeks biodiversitas 0 (nol), artinya tidak terdapat biodiversitas vegetasi di lokasi sampel. Jenis yang teridentifikasi hanya sejenis yaitu jenis vegetasi komersial yang mempunyai nilai jual dan ekonomi tinggi berupa kelapa sawit, karet dan akasia. Lokasi lahan gambut di DAS Kampar telah mengalami konversi lahan gambut menjadi perkebunan kelapa sawit, karet dan hutan tanaman industri untuk ditanam tanaman homogen yang dianggap mampu menunjang perekonomian. Kondisi ini menyebabkan fauna kehilangan habitatnya, karena sudah tidak ada lagi vegetasi-vegetasi yang dapat menjadi daya dukung baik untuk makanan maupun tempat berlindung bagi hewanhewan. Banyak hewan yang melakukan migrasi ke tempat lain untuk mencari tempat tinggal baru, bahkan tidak jarang sampai masuk ke dalam pemukiman penduduk karena tidak adanya tempat bagi hewanhewan lagi.

Delapan lokasi sampel penelitian yang dilakukan untuk melihat konversi lahan gambut yang terjadi di DAS Kampar Provinsi Riau Sumatera, masih ada satu lokasi yang teridentifikasi tutupan lahannya sebagai hutan primer yang mempunyai biodiversitas vegetasi sedang (cukup banyak jenisnya). Menurut pengakuan masyarakat setempat dan beberapa orang tokoh serta beberapa pimpinan karyawan perusahaan yang ada di lokasi lahan gambut, bahwa lokasi Desa Sanggar merupakan lokasi 
lahan gambut dengan tutupan lahan berupa hutan primer yang banyak dijumpai jenis-jenis vegetasi lahan basah yang tumbuh di atasnya. Jenis vegetasi yang ada di lokasi Desa Sanggar ini mempunyai nilai ekonomi tinggi, karena jenis-jenis vegetasinya merupakan jenis kayukayu yang kuat dan baik digunakan untuk pembangunan rumah maupun lainnya. Kondisi ini membuat maraknya terjadi pembalakan kayu-kayu untuk dikomersilkan oleh oknumoknum yang tidak bertanggung jawab dan tidak memperhatikan ketahanan lingkungan. Banyak kayu-kayu dari biodiversitas vegetasi di hutan primer lahan gambut Desa Sanggar hilang dan punah. Penghitungan nilai indeks biodiversitas vegetasi menunjukkan bahwa Desa Sanggar merupakan desa yang mempunyai nilai indeks 2,83 masuk ke dalam kategori biodiversitas sedang. Meskipun tutupan lahan berupa hutan primer, namun sudah terjadi penebangan liar kayu-kayu yang ada di dalam hutan primer.
Pembalakan yang dilakukan secara liar tanpa memperhatikan kelestarian lingkungan menyebabkan hilangnya vegetasi dan menurunnya daya dukung lingkungan untuk mendapatkan ketahanan lingkungan yang diperlukan oleh unsur-unsur komponen lingkungan yang berada di dalamnya. Inventarisasi jenis vegetasi endemik lahan gambut Desa Sanggar DAS Kampar Provinsi Riau Sumatera hanya ditemukan 16 jenis vegetasi. Vegetasi endemik lahan gambut tersebut dapat dilihat pada tabel 5 .

Jenis-jenis vegetasi lahan gambut sangat banyak hampir berkisar 300 jenis, seperti yang disebutkan oleh Giesen (1991), bahwa di Taman Nasional Berbak Jambi ditemukan sebanyak lebih 160 jenis vegetasi lahan gambut. Hutan primer lahan gambut di Desa Sanggar hanya ditemukan sebanyak 50 jenis saja 16 jenis di antaranya masuk ke dalam vegetasi endemik lahan gambut. Vegetasi endemik ini merupakan vegetasi yang masih

Tabel 5

Jenis-Jenis Vegetasi Endemik Lahan Gambut Di Desa Sanggar DAS Kampar Provinsi Riau Sumatera

\begin{tabular}{cllc}
\hline No & \multicolumn{1}{c}{ Nama lokal } & \multicolumn{1}{c}{ Nama spesies } & Jumlah \\
\hline 1 & Balam & Diospyros sumatrana Miq & 33 \\
2 & Bintangur & Calophyllum insularum & 81 \\
3 & kelat & Austrobuxus nitidus Miq. & 45 \\
4 & Kelat Pisang & Ilex hypoglauca Loes. & 37 \\
5 & Malas & Parastemon urophyllus (Wall. Ex.A. DC) A.DC & 20 \\
6 & Medang & Nothaphoebe coriacea (Kosterm.) Kosterm. & 5 \\
7 & Mendarahan & Horsfieldia crassifolia (Hook.f. \& Thomson) Warb. & 57 \\
8 & Meranti Bakau & Shorea platycarpa & 30 \\
9 & Meranti Bunga & Shorea teysmanniana & 91 \\
10 & Para-para & Aglaia rubiginosa (Hiern) Pannell. & 15 \\
11 & Pelawan & Tristaniopsis merguensis (Griff) Peter G.Wilson \& J.T Water & 35 \\
12 & Punak & Tetrameristra glabra Miq. & 25 \\
13 & Ramin & Gonystylus bancanus & 8 \\
14 & Rengas & Glutha rengas L. & 11 \\
15 & Suntai & Palaquium walsurifolium Pierre ex Dubard & 1 \\
16 & Terentang & Campnosperma coriaceum (Jack) Hallier f. & 25 \\
\hline
\end{tabular}

Sumber : data primer 2017 
bertahan hidup dengan segala gangguan dan ancaman yang dilaluinya. Mengingat vegetasi endemik ini adalah vegetasi berkayu yang mempunyai nilai ekonomi tinggi, sehingga banyak terjadi perambahan kayu-kayu yang tidak bertanggung jawab. Namun saat ini sudah mulai timbul kesadaran dari masyarakat dan para pemuka adat serta para pemimpin perusahaan untuk menjaga keberadaan hutan primer. Upaya yang dilakukan dengan menanam kembali jenis vegetasi yang sudah langka, punah dan hilang agar jenis-jenisnya bertambah banyak.

Lokasi Desa Sanggar dipertahankan untuk dapat menjadi hutan primer dengan biodiversitas tinggi. Patroli oleh masyarakat dan perusahaan yang ada di sekitar hutan primer Desa Sanggar saat ini dilakukan dengan ketat agar tidak terjadi pembalakan dan penebangan secara liar. Namun secara hukum adat tersirat bahwa kayu-kayu di dalam hutan primer lahan gambut di Desa Sanggar ini dapat digunakan atau ditebang, namun hanya sekedar untuk memenuhi kebutuhan bagi masyarakat setempat. Kegunaan kayu-kayu yang boleh ditebang adalah untuk pembuatan fasilitas umum seperti rumah adat, rumah sakit, rumah ibadah dan pembuatan rumah bagi masyarakat yang tidak mampu setelah mendapatkan persetujuan dari para tetua dan ketua adat setempat.

Selain tutupan lahan berupa vegetasi lahan gambut, keberadaan mikro organisme yang ada di lahan gambut yang mengalami konversi juga menjadi terganggu. Keberadaan mikro organisme di lahan gambut DAS Kampar sangat penting untuk proses penguraian bahanbahan organik dari sisa tumbuhan yang sudah mati. Seperti teridentifikasi di satu lokasi sampel terdapat banyak mikro organisme yang masih dapat bertahan hidup, namun di tempat lain yang juga telah mengalami konversi lahan hanya sedikit mikro organisme yang dijumpai dengan variasi komposisi dan bentuk yang berbeda. Ketidakstabilan kondisi ini akibat konversi lahan yang dilakukan, sehingga berdampak kepada kehidupan mikro organisme di dalamnya. Mikro organisme yang masih dapat beradaptasi dengan gangguan dan kondisi lahan yang mengalami konversi akan bertahan hidup, namun yang tidak dapat beradaptasi dengan kondisi perubahan lingkungan yang terjadi akan terseleksi dengan sendirinya. Di lokasi sampel penelitian dilakukan penghitungan mikro organisme berupa bakteri dan jamur. Hasil penghitungan di laboratorium diperoleh 16 isolat bakteri dan 15 isolat jamur. Jumlah isolat bakteri dan jamur ini dapat dilihat pada tabel 6.

Perubahan tutupan lahan yang dikonversi menjadi perkebunan kelapa sawit, karet dan hutan tanaan industri menyebabkan terjadi perubahan secara global pada kehidupan mikro organisme di DAS Kampar Provinsi Riau Sumatera, sehingga tidak banyak mikro organisme yang bisa dijumpai. Bakteri yang terdapat di DAS Kampar ini hanya teridentifikasi mempunyai dua bentuk saja, yakni bentuk batang yang mendominasi dari bakteri dan sebagian kecil berbentuk bulat. Jamur yang dijumpai di lahan gambut DAS Kampar juga hanya teridentifikasi sebanyak empat ordo saja. Bentuk bakteri dapat dilihat dari gambar 4.

Bakteri dengan bentuk batang mendominasi bentuk sel yang ada di lahan gambut DAS Kampar, hanya 3 (tiga) sel bakteri saja yang mempunyai bentuk bulat dari 16 isolat bakteri yang ditemukan. Hilangnya ketahanan lahan gambut yang dibutuhkan oleh bakteri akibat konversi lahan yang terjadi menyebabkan tidak banyak variasi bentuk sel 
Wirdati Irma, Totok Gunawan, Suratman -- Pengaruh Konversi Lahan Gambut Terhadap Ketahanan Lingkungan di DAS Kampar Provinsi Riau Sumatera

Tabel 6

Jumlah Isolat Bakteri Dan Jamur Di Lahan Gambut DAS Kampar Provinsi Riau Sumatera

\begin{tabular}{|c|c|c|c|c|c|}
\hline \multirow{2}{*}{ No } & \multirow{2}{*}{ Lokasi Penelitian } & \multicolumn{2}{|c|}{ Isolat } & \multicolumn{2}{|c|}{ Jmh koloni } \\
\hline & & Bakteri & Jamur & Bakteri $\left(10^{4}\right)$ & Jamur $\left(10^{5}\right)$ \\
\hline \multirow[t]{2}{*}{1} & Subarak & T1 Subarak P5 (1) & T1 Subarak & 46,19 & 5 \\
\hline & & T2 Subarak P3 (3) & T2 Subarak & & \\
\hline \multirow[t]{2}{*}{2} & Lubuk Sakat & T1 Lubuk Sakat P3 (1) & T1 Lubuk Sakat & 22,25 & 6,5 \\
\hline & & T2 Lubuk Sakat p3 (2) & T2 Lubuk Sakat & & \\
\hline \multirow[t]{2}{*}{3} & Rantau Baru & T1 Rantau Baru P4 (2) & T1 Rantau Baru & 34,58 & 1500,5 \\
\hline & & T2 Rantau Baru P5 (3) & T2 Rantau Baru & & \\
\hline \multirow[t]{2}{*}{4} & Kuala Terusan & T1 Kuala Terusan P3 (2) & T1 Kuala Terusan & 51,55 & 2001,33 \\
\hline & & T2 Kuala Terusan P4 (3) & T2 Kuala Terusan & & \\
\hline \multirow[t]{2}{*}{5} & Tanjung Punggai & T1 Tanjung Punggai P5 (1) & T2 Tanjung Punggai & 17,31 & 1000 \\
\hline & & T2 Tanjung Punggai P3 (2) & & & \\
\hline \multirow[t]{2}{*}{6} & Kutup & T1 Kutup P4 (1) & T1 Kutup & 13,6 & 863,75 \\
\hline & & T1 Kutup P5 (1) & T2 Kutup & & \\
\hline \multirow[t]{2}{*}{7} & Sanggar & T1 Sanggar P3 (2) & T1 Sanggar & 12,93 & 1344,33 \\
\hline & & T2 Sanggar P4 (1) & T2 Sanggar & & \\
\hline \multirow[t]{2}{*}{8} & Meranti & T1 Meranti P3 (1) & T1 Meranti & 24,55 & 1278,5 \\
\hline & & T2 Meranti P5 (1) & T2 Meranti & & \\
\hline
\end{tabular}

Sumber : data primer 2017

bakteri yang dapat bertahan hidup. Perubahan yang terjadi mengakibatkan beberapa bentuk bakteri yang lain tidak dapat beradaptasi dan bertahan hidup bersaing pada lingkungannya. Penelitian yang dilakukan oleh Irvan (2014), tentang isolat dan enumerasi bakteri tanah gambut di perkebunan kelapa sawit Kecamatan Tambang Kabupaten Kampar Provinsi Riau menemukan 12 isolat bakteri dengan 7 bentuk batang dan 5 bentuk kecil.

Jenis jamur yang ditemukan di lahan gambut DAS Kampar Provinsi Riau Sumatera berjumlah 4 ordo, yaitu Eurotiales, Helotiales, Hypocreales, dan Mucorales. Bakteri dan jamur merupakan mikro organisme yang berperan dalam merombak bahan-bahan organik yang berasal dari sisa-sisa tumbuhan yang sudah mati di lahan gambut. Jika lingkungan habitat mikro organisme jamur dan bakteri ini mengalami kerusakan maka kedua jenis mikro organisme ini akan mengalami hambatan dan gangguan dalam melakukan perombakan tersebut, sehingga perombakan yang terjadi tidak sempurna. Gambar jamur yang ada di

Gambar 4

Bentuk Sel Bakteri Di Lahan Gambut DAS Kampar Riau Provinsi Riau

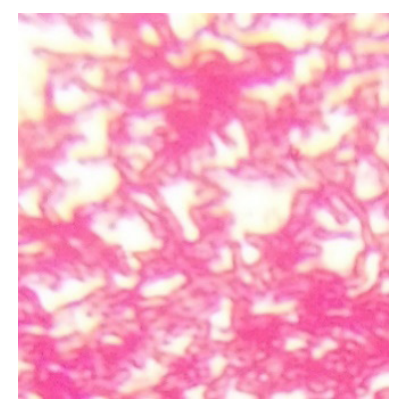

a. Bentuk bulat

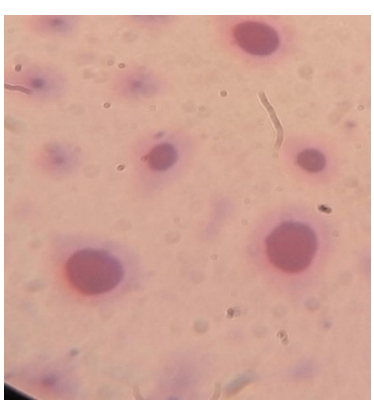

b. Bentuk batang

Sumber : Foto primer 2017 
Gambar 5

Bentuk Jamur Yang Dijumpai Pada Tanah Gambut Di DAS Kampar Provinsi Riau
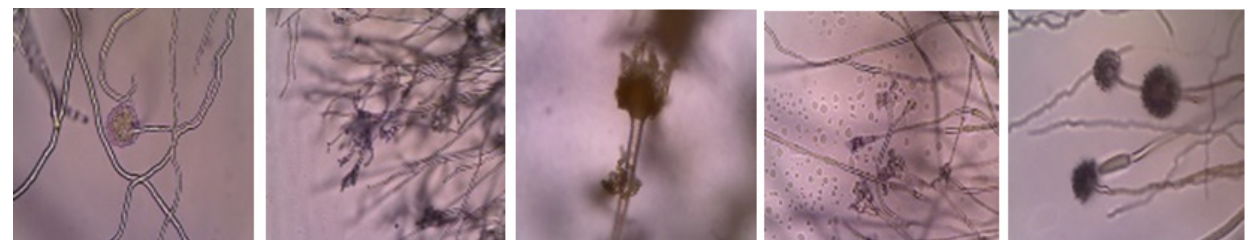

A. Ordo Eurotiales

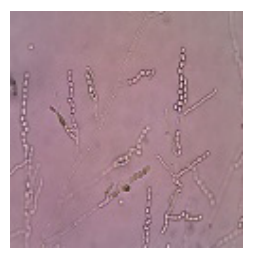

B. Helotiales
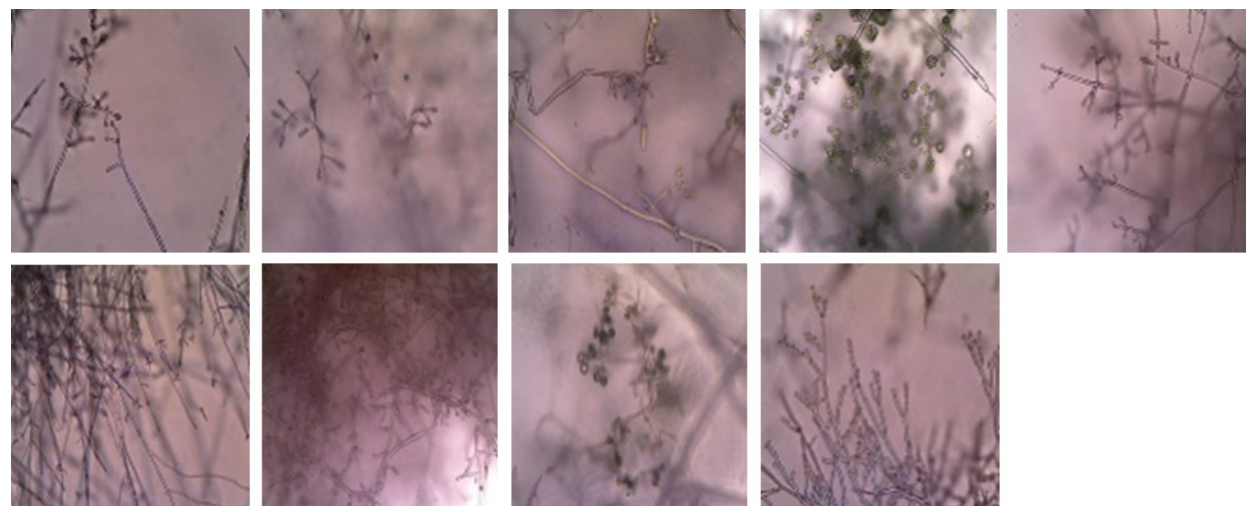

C. Hypocreales
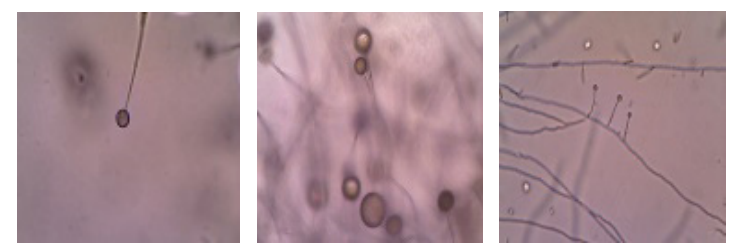

D. Mocorales

Sumber : Foto primer, 2017

lahan gambut DAS Kampar Provinsi Riau Sumatera dapat dilihat pada gambar 5.

Ordo Hypocreales merupakan jamur yang paling dominan dijumpai di lahan gambut DAS Kampar Provinsi Riau. Keberadaan jamur ini pada lahan gambut yang berada di bagian tengah sampai hilir DAS Kampar. Banyaknya jamur ini akan menyebabkan tanah gambut semakin subur karena semakin banyak jamur dapat melakukan proses dekomposer pada serasah bahan organik yang mati di lahan gambut. Salah satu faktor yang menyebabkan tanah subur adalah keberadaan faktor biologi berupa populasi mikroorganisme yang ada di dalamnya (Irvan, 2014).

Hilangnya daur kehidupan pada lahan gambut menyebabkan kestabilan lingkungan terganggu serta menyebabkan terjadinya gangguan dan penurunan ketahanan lingkungan lahan gambut dalam menjalankan fungsinya sebagai fungsi ekologi, sosial dan ekonomi. Ketahanan lingkungan yang 
rendah menimbulkan rentan bencana seperti kebakaran, asap, kebanjiran dan lainnya. Bencana yang timbul akibat kurangnya ketahanan lingkungan lahan gambut dapat berlangsung lama dan sulit untuk dipulihkan, mengingat lahan gambut merupakan lahan yang marginal.

Hilangnya ketahanan lingkungan lahan gambut yang menjadi salah satu aset terbesar di Provinsi Riau mengakibatkan kerugian yang sangat besar baik bagi lingkungan lahan gambut di Provinsi Riau secara khusus, maupun bagi lahan gambut secara keseluruahan termasuk manusia yang ada di dalamnya secara umum. Tidak dapat dipungkiri bahwa lahan gambut merupakan lahan yang banyak memberikan manfaat bagi lingkungan dan manusia baik secara ekologis, ekonomi dan sosial.

\section{SIMPULAN}

Berdasar penjelasan tersebut di atas dapat ditarik simpulan sebagai berikut.

Pertama, dijumpai konversi lahan gambut di DAS Kampar Provinsi Riau Sumatera di tujuh lokasi sampel penelitian yang menyebabkan terjadinya penurunan ketahanan lingkungan. Konversi lahan gambut terjadi pada kedalaman gambut dangkal sampai sangat dalam, berupa perkebunan kelapa sawit, perkebunan karet, hutan tanaman industri, dan permukiman.

Kedua, nilai indeks biodiversitas vegetasi masuk ke dalam kategori rendah sampai dengan sedang dengan nilai Indeks ( $\left.\mathrm{H}^{\prime}\right)$ sebesar 0 2,83 . Kategori nilai indeks biodiversitas ini disebabkan oleh banyaknya terjadi konversi lahan gambut. Kondisi ini dapat menyebabkan berkurang bahkan hilangnya daya dukung lingkungan untuk ketahanan lingkungan dalam menjaga ketahanan wilayah lahan gambut di DAS Kampar Provinsi Riau.

\section{DAFTAR PUSTAKA}

Anonimous, 2006, Lahan Gambut Terkait Perubahan Iklim, Fact Sheet, http:// assets.wwfid.panda.org/downloads/ faqgambut.pdf, diunduh tanggal 30 April 2018.

Asrofi, A 2017, Strategi Adaptasi Masyarakat Pesisir Dalam Penanganan Bencana Banjir Rob dan Implikasinya Terhadap Ketahanan Wilayah (Studi di Desa Bedono Kecamatan Sayung Kabupaten Demak Jawa Tengah), Jurnal Ketahanan Nasional, Vol. 23, no 2, hh. 125-144.

Barchia, M,F 2012,Gambut; Agroekosistem dan Transformasi Karbon, Yogyakarta: Gadjah Mada Press.

Cassel, D,K 1997, Aquic Conditions and Hydric Soils: The Problems Soils Foreword, Dalam: M, J, Veppraskas \& S, W, Sprecher,(eds), SSSA Special Publication Number 50.

Casson, A., 2002, A forest of palms: The political economyof Indonesia's oil palm sub-sector and the fate of theforest, in C.J.P. Colfer and I.A.P. Resosudarmo (eds.), Which way forward People, forests and policymakingin Indonesia, hh. 221245. Singapore: Institute of Southeast Asian Studies.

Djufri, 2013, Komposisi Flora Kawasan Rawa Tripa di Kabupaten Aceh Barat, Jurnal Edubio Tropika, Vol. 1, No. 1, hh. 1-60

Giesen, W 1991, Berbak Wildlife Reserve, Jambi, Reconnaisance Survey Report, PHPA/AWB, Sumatera Wetland Project Report, No. 13, Bogor.: Asean Wetland Bureau-Indonesia,

Holidi, Syafriyani, E, Warjianto \& Sutejo, 2015, Pertumbuhan Bibit Kelapa Sawit Pada Tanah Gambut Berbagai Ketinggian 
Genangan, Jurnal Ilmu Pertanian, Vol. 18 No. 3, hh. 135-140

Iqbal, Muhammad \& Sumaryanto, 2007, Strategi Pengendalian Alih Fungsi Lahan Pertanian Bertumpu Pada Partisipasi Masyarakat. Jurnal Analisis Kebijakan Pertanian, Vol. 5, No. 2, hh. 167-182.

Irvan, M 2014, Isolasi dan Enumerasi Bakteri

Tanah Gambut di Perkebunan Kelapa Sawit PT. Tambang Hijau Kecamatan Tambang Kabupaten Kampar, Jurnal Agroteknologi, Vol. 5, No. 1, hh. 1-8.

Janti, G.I, Martono, E \& Subejo, 2016, Perlindungan Lahan Pertanian Pangan Berkelanjutan Guna Memperkokoh Ketahanan Pangan Wilayah (Studi di Kabupaten Bantul, Daerah Istimewa Yogyakarta, Jurnal Ketahanan Nasional, Vol. 22, No. 1, hh. 1-21.

Jauhiainen, J, A, Hooijer \& S,E 2012, Carbondioxide emissions from an acacia plantation onpeatland in Sumatra, Indonesia, Journal Biogeosciences, Vol. 9, hh.617-630.

Jaya, P, H, I 2018, Nasib Petani dan Ketahanan Pangan Wilayah (Studi Tentang Kebijakan Pemerintah dan Respons Masyarakat Desa Mulyodadi, Bantul Ketika Harga Komoditas Pertanian Naik), Jurnal Ketahanan Nasional, Vol. 24, no. 1, hh. 77-93.

Las,I, K, Nugroho, \& A. Hidayat, 2008, Strategi Pemanfaatan Lahan Gambut Untuk Pengembangan Pertanian Berkelanjutan. Jurnal Pengembangan Inovasi Pertanian, Vol. 2(4): hh. 295-298. . Bogor : Balai Besar Penelitian dan Pengembangan Sumberdaya Lahan Pertanian.

Lemhannas, 2000, Ketahanan Nasional, Jakarta: Balai Pustaka.
Lisdayanti, Hikmat, A \& Istomo, 2016, Komposisi Flora dan Keragaman Tumbuhan di Hutan Rawa Musiman, Rimbo Tujuh Danau Riau, Jurnal Penelitian Hutan dan Konversi Alam, Vol. 3 No 1, hh. 15-28.

Koh, L, P \& D,S, Wilcove 2008, Is oil palm agriculturereally destroying tropical biodiversity, Conservation Letters, Vol.1, No. 2, hh, 1-5.

Miettinen, J, C, Shi and S,C, Liew 2012, Two decades ofdestruction in Southeast Asia's peat swamp forests, Frontiers in Ecology and the Environment, Vol.10, No. 3, hh. 124-128.

Qomar, N, \& Jaya, Y,V 2010, Deforestasi dan Penggunaan Lahan Lansekap Semenanjung Kampar, Riau, Seminar dan Lokakarya Revitalisasi dan Penguatan Jejaring Kerjasama Pusat Penelitian Lingkungan Hidup, Pekanbaru 19-20 November 2010.

Radjagukguk, B 2000, Perubahan sifat-sifat fisik dan kimia tanah gambut akibat reklamasi lahan gambut untuk pertanian, Jurnal Ilmu Tanah dan Lingkungan, Vol. 2 No, hh. 1- 15.

Rustiadi, E. dan W. Reti, 2008, Urgensi LahanPertanian Pangan Abadi dalam PerspektifKetahanan Pangan, dalam Arsyad,S dan E.Rustiadi (Ed), Penyelamatan Tanah, Air dan Lingkungan, Jakarta : Crestpent Pressdan Yayasan Obor Indonesia.

Sabiham, S 2007, Pengembangan Lahan Secara Berkelanjutan Sebagai Dasar Dalam Pengelolaan Gambut di Indonesia, Makalah Utama Seminar Nasional Pertanian Lahan Rawa, Kapuas 3-4 Juli 2007. 
Soil Survey Staff, 1999, Kunci Taksonomi Tanah, Edisi Kedua Bahasa Indonesia, Pusat Penelitian Tanah dan Agroklimat, Badan Penelitian dan Pengembangan Pertanian.

Sukandarrumidi, 2008, Batubara dan Gambut, Gadjah Mada University Press, Yogyakarta

Sukandarrumidi, 2009, RekayasaGambut Briket Batubara, dan Sampah Organik; Usaha Memanfaatkan Sumberdaya Alam yang Terpinggirkan, Yogyakarta.: Gadjah Mada University Press.

Suwondo, Sabiham, S, Sumardjo, \& Bambang Paramudya, 2010, Analisis Lingkungan Biofisik Lahan Gambut pada Perkebunan Kelapa Sawit Jurnal Hidrolitan, Vol. 1, no. 3 , hh. 20-28

Thorburn, C, C \& Kull, C, A 2015, Peatlands and plantations in Sumatra, Indonesia: Complex realities for resource governance, ruraldevelopment and climate change mitigation, Jurnal Asia Pasific Viewpoint, Vol. 56, No. 1, hh. 153-168.

Wahyunto, Dariah, A, Pitono, D \& Sarwani, M 2013, Prospek Pemanfaatan Lahan Gambut Untuk Perkebunan Kelapa Sawit di Indonesia, Perspektif, vol. 12 no. 1, hh. 11-12.

World Commission on Environment and Development(WCED), 1987, Our common future: Report of theworld commission on environment and development, Oxford: Oxford University Press.

\section{Peraturan Perundangan}

Peraturan Pemerintah Nomor 57 Tahun 2016 Tentang Perubahan Atas Peraturan Pemerintah Nomor 71 Tahun 2014 Tentang Perlindungan dan Pengelolaan Ekosistem Lahan Gambut. 